\title{
APONTAMENTOS PARA O RECONHECIMENTO DAS UNIÕES HOMOSSEXUAIS FACE AO PARADIGMA DO ESTADO DEMOCRÁTICO DE DIREITO
}

\author{
Fernando Horta Tavares, Iara Antunes de Souza, \\ Isaac Espíndola Vitorino Ferreira, Tiago Vieira Bomtempo \\ REPORTING FOR THE RECOGNITION OF HOMOSEXUAL UNIONS \\ TO THE DEMOCRATIC STATE
}

\section{RESUMO}

ESTE ARTIGO PRETENDE TRAZER APONTAMENTOS SOBRE 0 RECONHECIMENTO DAS UNIÕES HOMOSSEXUAIS COMO ENTIDADES FAMILIARES NO CONTEXTO dO ESTADO DEMOCRÁTICO DE DIREITO. PARA TANTO, ADOTA-SE INTERPRETAÇÃO NO SENTIDO DE QUE O ARTIGO 126, § $4^{\circ}$ DA CONSTITUIÇÃO DE 1988 É UMA CLÁUSULA ABERTA, INCLUINDO O TEMA, QUE DEVE SER ENTENDIDO À LUZ DE OUTROS PRINCÍPIOS CONSTITUCIONAIS, TAIS COMO OS PRINCÍPIOS DE IGUALDADE, LIBERDADE E DA DIGNIDADE DA PESSOA HUMANA.

\section{PALAVRAS-CHAVE}

HOMOSSEXUALIDADE; UNIÕES HOMOSSEXUAIS; ENTIDADE FAMILIAR; DIREITO DE FAMÍlIA; CLÁUSULA ABERTA; EsTAdo DEMOCRÁtico DE DIREITO.

\section{ABSTRACT}

THIS ARTICLE AIMS TO BRING NOTES ABOUT THE RECOGNITION OF HOMOSEXUAL UNIONS AS FAMILY ENTITIES IN THE CONTEXT OF THE DEMOCRATIC STATE OF LAW. TO DO SO A INTERPRETATION of ARTICLE 126, \& 40. OF THE 1988 CONSTITUtION IS ADOPTED IN THE SENSE OF OPEN CLAUSE INCLUDING THE SUBJECT WHICH MUST BE UNDERSTOOD IN THE LIGHT OF OTHER CONSTITUTIONAL PRINCIPLES, SUCH AS THE PRINCIPLES OF EQUALITY, FREEDOM AND DIGNITY OF THE HUMAN PERSON.

\section{KEYWORDS}

HOMOSEXUALITY; HOMOSEXUAL UNIONS; FAMILIAR ENTITY; FAMILY LAW; CLAUSE OPEN; DEMOCRATIC STATE OF LAW.

\section{INTRODUÇÃO}

A palavra homossexual vem do grego homo ou homeo, elemento de composição que exprime a ideia de semelhança, igual, análogo, ou seja: homólogo ou semelhante ao sexo que a pessoa figura, ou aspira ter (OLIVEIRA, 1997, p. 310).

A psicologia e a medicina entendem que a homossexualidade seria a atração erótica por indivíduos do mesmo sexo. O homossexual é aquele que pratica atos libidinosos com indivíduos do mesmo sexo ou ainda possui fantasias eróticas envolvendo esse tipo de situação.

A homossexualidade sempre existiu na história da humanidade. Porém, com o advento da Igreja Católica, esta forma de vida passou a ser tratada como "doença", 
repudiada pela sociedade, sendo até mesmo caracterizada como crime em alguns países de religião mulçumana.

Atualmente o conceito de "homossexualismo" mudou no campo científico, deixando de ser considerado uma patologia pela medicina. Assim como a heterossexualidade, a homossexualidade é tida como um estado mental. Não há nenhuma doença, desvio de comportamento ou perversão, como se pretendeu até a algum tempo atrás.

Em dezembro de 1973, a APA (Associação Psiquiátrica Americana) propôs e aprovou a retirada da homossexualidade da lista de transtornos mentais. Em 1985, o Conselho Federal de Medicina do Brasil (CFM) retirou a homossexualidade da condição de desvio sexual. Na década de 1990, o Manual Diagnóstico e Estatístico de Transtornos Mentais (DSM-IV), onde são identificados por códigos todos os distúrbios mentais, servindo de orientador para a classe médica, principalmente para os psiquiatras, também retirou a homossexualidade da condição de distúrbio mental. Em 1993, a Organização Mundial de Saúde (OMS) retirou o termo "homossexualismo" e passou a adotar o termo homossexualidade. Já em 1995, na última versão da Classificação Internacional das Doenças (CID), o termo homossexualismo deixou de constar nos diagnósticos (MIRANDA, 2006, pp. 7-8).

O sufixo "ismo", que significa doença, foi retirado e substituído pelo sufixo "dade", que designa modo de ser. Os cientistas concluíram que o "homossexualismo" não podia ser sustentado enquanto diagnóstico médico. (MIRANDA, 2006, pp. 7-8). Isto porque fora observado que os transtornos dos homossexuais realmente decorrem muito mais de sua discriminação e repressão social derivados do preconceito do seu desvio sexual. Desde 1991, a Anistia Internacional considera violação aos direitos humanos a proibição da homossexualidade.

Com fundamento no paradigma do Estado Democrático de Direito, aos homossexuais devem ser assegurados os mesmos direitos estabelecidos a qualquer pessoa, nos termos da Constituição. Eles têm que ter a mesma oportunidade de constituir família, como é garantido aos casais heterossexuais, em consonância com os princípios constitucionais de um Estado Laico e de uma sociedade pluralista. Tais assertivas serão objeto de estudo no decorrer deste artigo.

Sob esta perspectiva, este artigo abordará a união homossexual, guiada como um modelo de entidade familiar, sustentada pelo novo conceito constitucional da família.

Para tanto, primeiramente, vai-se demonstrar o tratamento da Família no ordenamento jurídico brasileiro, perpassando pelo conceito constitucional em conformidade com paradigma do Estado Democrático de Direito e os modelos previsto no Código Civil de 2002. Após, discorre-se sobre o tratamento dado às uniões homossexuais pela jurisprudência brasileira e no direito comparado. Propõe-se, ainda, o reconhecimento da união homossexual como forma de entidade familiar a partir da ideia isonômica contida Constituição da República de 1988. Por fim, apresenta-se um breve estudo acerca da união homossexual e da união estável, cujas disposições sobre 
o tema são de lege ferenda e o estudo de duas ações em tramitação junto ao STF visando o reconhecimento da união homossexual. Tudo, com o fito de se fazer um estudo acerca das uniões homossexuais sob a ótica do Estado Democrático de Direito.

\section{A FAmília no ORdenamento Jurídico BRASileiro}

\section{I O Conceito constitucional de família no Estado Democrático de Direito}

A Constituição da República Federativa do Brasil de 1988, batizada por Ulisses Guimarães como “Constituição Cidadã”, é um marco na história do Brasil ao representar uma ruptura com o antigo regime autocrático e ditatorial, inspirado em anseios liberais, e instaurar uma nova ordem jurídica, afirmando direitos e garantias individuais compatíveis com os ideais democráticos.

É neste contexto que principia o artigo $1^{\circ}$ da Carta Constitucional:

A República Federativa do Brasil, formada pela união indissolúvel dos Estados e Municípios e do Distrito Federal, constitui-se em Estado Democrático de Direito e tem como fundamentos:

I - a soberania;

II - a cidadania;

III - a dignidade da pessoa humana; [...] (grifo nosso) (BRASIL, 2008, p. 7)

Faz-se mister salientar, contudo, que os princípios basilares desta nova ordem jurídica estão dispersos ao longo do texto constitucional, exigindo-se para sua devida apreciação uma interpretação sistemática e coerente de seus institutos, assegurando, destarte, a harmonia de todo o ordenamento jurídico, cujas diretivas despontam na Constituição de 1988.

Notório pela sua extensão, e bem mais pelas garantias que encerra, apregoa o caput do artigo $5^{\circ}$ da Constituição da República de 1988:

Todos são iguais perante a lei, sem distinção de qualquer natureza, garantindo-se aos brasileiros e aos estrangeiros residentes no País, à inviolabilidade do direito à vida, à liberdade, à igualdade, à segurança e à propriedade, nos termos seguintes: [...] (BRASIL, 2008, p. 7).

Neste momento, percebe-se a desafiadora missão dos intérpretes do direito que tem por escopo apreender o ordenamento jurídico vigente a partir das prerrogativas consagradas no texto constitucional, cuja finalidade precípua é a promoção da dignidade da pessoa humana no Estado Democrático de Direito. Neste sentido, corrobora Cesar Fiúza (2003, p. 29), ao ponderar que: 
Vive-se hoje no Brasil os alvores do Estado Democrático de Direito. Este é o momento da conscientização desse novo paradigma. Só agora assumem a devia importância os princípios e os valores constitucionais por que se deve pautar todo o sistema jurídico. Constitucionalização ou publicização do Direito Civil entram na temática do dia. [...] Diz-se que os pilares de sustentação do Direito Civil, família, propriedade e autonomia da vontade, deixaram de sê-lo. O único pilar que sustenta toda a estrutura é o ser humano, a dignidade da pessoa, sua promoção espiritual, social e econômica.

É neste sentido que se anuncia, no momento presente, uma crise do direito concernente à apreensão e interpretação de seus institutos, uma vez que a Constituição de 1988 propõe uma nova visão acerca de temas outrora estratificados pela doutrina tradicional.

Movimento diverso não ocorreria no direito das famílias, especificamente contemplado pelo artigo 226 da Constituição da República, mas cujos postulados e princípios não são outros senão aqueles que conformam o Estado Democrático de Direito e promovem a efetivação dos direitos e garantias estabelecidos na Magna Carta, conforme explicita o mencionado Fiuza (2003, pp. 28-29):

O direito de família está em crise. A mesma Revolução Industrial que gerou a crise do Direito das Obrigações, esta mesma Revolução conduz a mulher para o mercado de trabalho, retira o homem do campo, proletariza as cidades, reduz o espaço de coabitação familiar, muda o perfil da família-padrão.

Em consonância com as mudanças sociais ocorridas nos últimos tempos, a Constituição de 1988 propõe um novo conceito de família, cujo conteúdo deve implicar a inclusão de novos arranjos familiares, ao reconhecer o pluralismo fático em que estes se desenvolvem. Ressalve-se, ainda, o compromisso com o bem de todos e com respeito à diferença, consectários da nova ordem jurídica, que não deve sucumbir a juízos retrógados de natureza moral e religiosa, não compatíveis com os princípios conformadores do Estado Democrático de Direito.

Outrossim, o Estado Democrático de Direito exige a garantia de iguais liberdades fundamentais (HABERMAS, 2003, p. 128-131.), o que implica a co-existência de vários projetos de vida.

Neste cenário, despontam os novos modelos familiares, designados de entidades familiares pela Constituição de 1988, como a família monoparental e a família anaparental. Entretanto, como brevemente se discorrerá neste trabalho, o rol apresentado pelo artigo 226, parágrafo $4^{\circ}$, da Constituição, afigura-se eminentemente exemplificativo, comportando outros arranjos, ainda que alguns deles sejam alvo recorrente de polêmicas e controvérsias. 
Por isso, não se fala mais em direito de família e sim em direito das famílias!

\section{I.2 OS MOdelos De família INSERIDOS PELo Código Civil De 2002}

Os modelos de família inseridos pelo Código Civil de 2002 são o casamento e a união estável. O casamento, conforme o artigo 1.511 do referido Código, estabelece comunhão plena de vida, com base na igualdade de direitos e deveres dos cônjuges.

A partir desta disposição, existem várias correntes que definem a natureza do casamento. Uma primeira, de natureza institucionalista, para qual o casamento é uma instituição social, na medida em que é conjunto de regras aceitas por todos para regular as relações entre os cônjuges. Para uma segunda, de natureza contratual, o casamento é um acordo de vontades, sendo um certo tipo de contrato especial, em relação aos direitos e deveres peculiares que possui. Há, ainda, alguns autores que entendem que, enquanto celebração, o casamento é contrato, e, enquanto vida comum, é uma instituição social (FIUZA, 2006, p. 944).

Prosseguindo-se o estudo, de acordo com o artigo 1.514 do Código Civil, "O casamento se realiza no momento em que o homem e a mulher manifestam perante o juiz, a sua vontade de estabelecer vínculo conjugal, e o juiz declara casados."

Assim, afirma César Fiúza (2006, p. 943) que: "Segundo nosso Direito em vigor, casamento é a união estável e formal entre homem e mulher, com o objetivo de satisfazer-se e amparar-se mutuamente, constituindo família.”

Desta forma, este dispositivo infraconstitucional não abre espaço para o casamento entre pessoas do mesmo sexo, como também não o faz correlato constitucional que exige a diversidade de sexos.

Com o advento do Código Civil de 2002 houve algumas inovações, em especial a diminuição dos objetivos do casamento, que aboliu a finalidade da procriação, da satisfação sexual e de constituir ou legitimar a família, através do reconhecimento da união estável como entidade familiar, conforme disposto em seu artigo 1.723, que será tratada logo abaixo.

Também, não é mais finalidade do casamento o tratamento adequado dos filhos, com a proteção de seus direitos, visto que de acordo com o artigo 1.596, os filhos havidos ou não na constância do casamento possuem as mesmas proteções e prerrogativas.

Ainda que o Código Civil de 2002 tenha inovado, no sentido do reconhecimento da união estável, o casamento possui formalidades que lhe asseguram certos direitos, como a possibilidade dos cônjuges adotarem o nome um do outro.

No que tange à união estável, o caput do artigo 1.723 do Código Civil de 2002, prevê que: "É reconhecida como entidade familiar a união estável entre o homem e a mulher, configurada na convivência pública, continua e duradoura e estabelecida com o objetivo de constituição de família.”

Para César Fiúza (2006, p. 969): 
União estável é a convivência pública, contínua e duradora sob o mesmo teto ou não, entre homem e mulher não ligados entre si pelo casamento, com a intenção de constituir família. O entendimento mais moderno é que seja dispensável o mos uxoruis, ou seja, a convivência idêntica ao casamento. Bastam a publicidade, a continuidade e constância das relações, para além de simples namoro ou noivado [...]. Pode haver, portanto, união estável sem que haja coabitação e vida idêntica à do casamento, embora deva estar presente a intenção de constituir família. Esta intenção traduz-se na prática de viver juntos, compartilhando o dia a dia, criando uma cumplicidade, uma comunhão de vida, amparando-se e respeitando-se reciprocamente [...].

A união estável é permitida aos solteiros, viúvos, divorciados, separados judicialmente, e tem como inovação inserida no Código Civil de 2002, a possibilidade de pessoas separadas de fato constituírem união estável válida, o que não era possível anteriormente pela Lei n. 8.791/94.

São assegurados aos companheiros o direito de prestar alimentos reciprocamente, direitos sucessórios, porém reduzidos em relação ao casamento em regra, e o regime de comunhão parcial de bens.

O referido código não estabelece tempo para a configuração da união estável, basta somente o preenchimento dos requisitos do artigo 1.723 do Código Civil.

Ainda, os companheiros poderão obter, a qualquer tempo e de comum acordo, a conversão da união estável em casamento, mediante requerimento ao juiz, com o assento no Registro Civil.

Assim como no casamento, a união estável não está prevista para pessoas do mesmo sexo, onde é reconhecida entre homem e mulher, de acordo com o art. 1.723 do Código Civil de 2002, não abrindo nem mesmo brechas para algum tipo de direito ou mesmo a possibilidade da união homossexual, no que tange aos seus efeitos, por se tratarem de entidades familiares distintas.

Conclui-se que o Código Civil de 2002 não trouxe os avanços pertinentes ao direito das famílias, estando em desacordo com o artigo 226 da Constituição da República de 1988, pois não prevê a união homossexual e outras formas de entidades familiares, tais como a monoparental, formada por qualquer dos pais, e a anaparental, formada pelos seus descendentes. Afinal, o referido artigo de nossa Constituição é uma cláusula aberta, não excluindo qualquer forma de entidade familiar.

\section{AS UNIÕES HOMOSSEXUAIS NA JURISPRUDÊNCIA BRASILEIRA}

Em que pese as uniões homossexuais ainda não gozarem de previsão legal, o seu reconhecimento e amparo encontra lugar junto a algumas manifestações do Poder Judiciário, em casos litigiosos que lhe são submetidos. 
Afinal, vivemos o pós-positivismo jurídico, onde o ordenamento jurídico é tido como um sistema aberto de princípios e regras, todos aptos a amparar os direitos que surgem ${ }^{1}$. Ademais, o Estado Democrático de Direito, nos garante e co-vivência de vários projetos de vida e iguais liberdades fundamentais (HABERMAS, 2003, pp. 128-131).

Assim, para fins de reconhecimento junto ao judiciário, a união homossexual segue (ou seguiu) o mesmo caminho que a união estável. A partir de reiteradas decisões judiciais reconhecendo este modelo de entidade familiar, o Poder Legislativo, posteriormente, conferiu a legalidade à união estável.

No entanto, a união homossexual ainda não logrou tal patamar. Esta busca, na tentativa de superação de várias barreiras e do preconceito, visa alcançar a sua legitimação e o reconhecimento por toda a sociedade. A jurisprudência brasileira, contudo, é minoritária no sentido do reconhecimento das uniões homossexuais, sendo que a maioria ainda a considera como sociedade de fato. A partir desta premissa o autor Guilherme Calmon Nogueira da Gama (1998, p. 491) entende que é possível:

[...] o reconhecimento do direito do partícipe da relação que for prejudicado em decorrência da aquisição patrimonial em nome tão somente do outro, ao partilhamento dos bens adquiridos durante a constância da sociedade de fato, na medida da sua efetiva contribuição para a formação ou o incremento patrimonial.

Não obstante, a força política e coesão dos grupos em defesa dos direitos dos homossexuais e a abertura cada vez maior da mídia tratando da homossexualidade põe em discussão o tema. À espera da normatização, elege-se a via judiciária no clamor ao reconhecimento da união homossexual, bem como os direitos advindos desta.

As primeiras decisões favoráveis à união homossexual ocorreram no Rio Grande do Sul, onde pioneiramente julgou-se que a competência para casos semelhantes seria das Varas de Família e não mais da Vara Cível (RIO GRANDE DO SUL, 1999).

A partir daí, surgiram novos julgados reconhecendo vários direitos à "entidade familiar homossexual”, principalmente quanto aos direitos sucessórios, vindo a união homossexual a ser reconhecida por um tribunal brasileiro em 2001, novamente no Tribunal do Rio Grande do Sul (RIO GRANDE DO SUL, 2001).

Deve-se mencionar também o reconhecimento da inelegibilidade em razão de uniões homossexuais, conforme determinou o Tribunal Superior Eleitoral (BRASIL, 2004) ao reconhecer que a união entre duas pessoas do mesmo sexo é uma "entidade familiar" e que se sujeita ao impedimento eleitoral existente em qualquer relação familiar.

Assim, Maria Berenice Dias (2008, p. 190) afirma que "[...] se estão sendo impostos ônus aos vínculos homoafetivos, faz-se mister sejam assegurados também 
todos os direitos e garantias a essas uniões no âmbito do Direito das Famílias e do Direito Sucessório”.

Consoante estes avanços jurisprudenciais, mas, ainda minoritários, colacionamse duas jurisprudências brasileiras, uma do Tribunal de Justiça de Minas Gerais e outra do Superior Tribunal de Justiça, as quais julgaram favorável o reconhecimento da união homossexual.

O processo n. 1.0024.06.9303247-6/001(1), julgado em 22.05.2007, pela desembargadora Heloísa Combat, do Tribunal de Justiça de Minas Gerais (MINAS GERAIS, 2007), trata do reexame e recurso de apelação interposto pelo Estado de Minas Gerais, contra a sentença proferida pelo juiz da $1^{\text {a }}$ Vara da Fazenda Pública e Autarquias da Comarca de Belo Horizonte, que julgou procedente pedido em ação ordinária, no que se refere à assistência médica e previdenciária ao companheiro homossexual.

A sentença de $1^{\text {a }}$ instância teve como fundamento os princípios da igualdade e isonomia, que, por extensão, possibilita às pessoas de mesmo sexo, que vivem em união homoafetiva, os mesmos direitos que àquelas que vivem em uniões heterossexuais.

Assim, o mencionado acórdão corroborou o entendimento da decisão de $1^{\circ}$ grau, julgando procedente o pedido da autora. Fundamentou que à união homoafetiva deve ser conferido o caráter de entidade familiar, pois preenche os requisitos da união estável entre casais heterossexuais, impondo-se reconhecer os direitos advindos daquela, sob pena de ofensa aos princípios da igualdade e da dignidade da pessoa humana. Ainda, que o artigo 226 da Constituição da República não pode ser analisado isoladamente, devendo respeitar os referidos princípios.

Segue este entendimento Luiz Edson Fachin ao afirmar que:

Tendo indiscutível valia instrumento que preenche vazio legislativo para expressar uma forma mais ampliada de compreensão das relações sociais apreendidas pelo Direito. O pronunciamento legislativo tem importância à medida que preenche um espaço jurídico de definição de valores e vincula o próprio julgador. Com virtudes e defeitos, toda manifestação legislativa pode ser um veículo situado no reconhecimento de uma mudança de padrões dentro e fora da família. (FACHIN, 1999, p.99).

Já o Recurso Especial n. 820.475, julgado em 02 de setembro de 2008, pelo Superior Tribunal de Justiça (BRASIL, 2008), julgou uma demanda em que se pede o reconhecimento da união homoafetiva. O processo teve origem na $4^{\mathrm{a}}$ Vara de Família de São Gonçalo, no Rio de Janeiro, onde “A.C.S e Outro” ajuizaram ação declaratória de união estável sob a alegação de preencherem os mesmos requisitos deste modelo de entidade familiar. A razão do pedido se justificava devido a um dos dois companheiros ser canadense e que tal reconhecimento garantiria o visto permanente a ele, uma vez que o outro é brasileiro. 
A sentença de $1^{\mathrm{a}}$ instância extinguiu o processo sob o fundamento de falta de previsão legal, conforme o artigo 267, inciso VI, do Código de Processo Civil. Em sede de apelação, a decisão de $1^{\circ}$ grau foi mantida pelo Tribunal de Justiça do Rio de Janeiro. Assim, as partes aviaram o Recurso Especial junto ao Superior Tribunal de Justiça.

Os recorrentes fundamentaram o recurso sustentando que o Tribunal a quo violou o princípio da identidade física do juiz, conforme artigo 132 do Código de Processo Civil, além da infringência aos artigos $4^{\circ}$ da Lei de Introdução ao Código Civil e 126 do Código de Processo Civil, sob o argumento que o ordenamento jurídico não veda o reconhecimento de união estável entre pessoas do mesmo sexo.

A Quarta Turma do Superior Tribunal de Justiça, por maioria, conheceu do recurso e deu-lhe provimento. O voto do relator, Ministro Antônio de Pádua Ribeiro, teve como fundamento o fato da inocorrência de ofensa ao princípio da identidade física do juiz. No entanto, no que se refere à impossibilidade jurídica do pedido ele declarou "ser pacífico o entendimento, tanto na doutrina quanto na jurisprudência, de que esta só se configura quando há expressa vedação dada pelo ordenamento jurídico.”

Afirma o Ministro que não há vedação expressa da união entre pessoas do mesmo sexo nos artigos 226, § $3^{\circ}$ da Constituição da República de 1988; e 1.723 e 1.724 do Código Civil de 2002. Assim, em que pese não existir uma regulação específica, o caso não deve ficar sem solução jurídica, devendo-se, portanto, aplicar a analogia, conforme os artigos $4^{\circ}$ da Lei de Introdução ao Código Civil e 126 do Código de Processo Civil.

Recorrendo novamente ao autor Luiz Edson Fachin, tem-se que:

Essa dedução, se de um lado pode gerar alguma perplexidade para a sustentação dos valores informativos das uniões tradicionais, por outro, pode ser um caminho, enquanto a norma específica não vier, para que os resultados buscados, dentro ou fora do Judiciário, sejam mais justos (FACHIN, 1999, p.100).

No mesmo raciocínio, afirma Maria Berenice Dias que:

O caminho está aberto, sendo imperioso que os juízes cumpram com a sua verdadeira missão: fazer Justiça. Acima de tudo, precisam ter sensibilidade para tratar de temas tão delicados como as relações afetivas, cujas demandas precisam ser julgadas com mais sensibilidade e menos preconceito. Os princípios de justiça, igualdade e humanismo devem presidir as decisões judiciais (DIAS, 2008, p.191).

Estas foram algumas jurisprudências apresentadas que demonstram o avanço significativo de nossos tribunais, que evoluem não só a nível estadual como também 
nacional. É um marco significativo na realidade dos homossexuais no Brasil e que abre precedentes não só para mais julgamentos favoráveis no reconhecimento das uniões homossexuais, bem como justifica a implementação de um dispositivo legal próprio que regule estas relações.

Entretanto, conforme será demonstrado no capítulo 5 do presente trabalho, a união homossexual encontra-se amparada pelo ordenamento jurídico através da cláusula aberta de entidades familiares da Constituição da República de 1988, não sendo necessário, para seu reconhecimento o recurso à analogia com os dispositivos legais referentes à união estável.

\section{As Uniões homossexuais no Direito eSTRANGeIro}

Em contra partida à ausência de tratativa legal específica das uniões homossexuais no Brasil, outros países já avançaram no sentido de conferir a elas proteção e eficácia jurídica.

A pioneira, neste caso, foi a Dinamarca, que por meio da Lei $\mathrm{n}^{\circ} 372$, de $1^{\circ}$ de junho de 1989, permitiu a aplicação da lei do casamento às uniões homossexuais, proibindo, contudo, a adoção. Exigia-se, ainda, que um dos parceiros tivesse residência permanente e nacionalidade dinamarquesa (REIS, 2005, p. 55).

Em 1993, a Noruega admitiu as uniões homossexuais com a edição da Lei $n^{\circ} 40$, possibilitando a participação conjunta da autoridade parental (AZEVEDO, 2004, p. 44).

Através do partenariat, o parlamento sueco oficializou as uniões homossexuais, a partir de $1^{\circ}$ de janeiro de 1995 , estabelecendo a intervenção obrigatória quando da dissolução da parceria. Em 1996, foi seguido pela Islândia, nos mesmos moldes dinamarqueses (AZEVEDO, 2004, p. 44).

Na Holanda, em 1991, passou-se a admitir o registro de uniões homossexuais em alguns municípios (REIS, 2005, p. 55).

Em 27 de fevereiro de 2004, a Suprema Corte da Califórnia negou liminarmente o pedido do Procurador-Geral Billy Lockyer, que requeria a suspensão imediata dos casamentos entre homossexuais e a anulação de mais de 3.500 realizados desde o dia 12 daquele mês (AZEVEDO, 2004, p. 44). Pendente a decisão definitiva, a questão do reconhecimento da união homossexual foi submetida a um plebiscito, sendo rejeitada pela população daquele estado norte-americano. Diante de tal fato, a Suprema Corte referendou a opção popular no sentido de não permitir novas uniões, garantindo-se, entretanto, a validade das realizadas anteriormente (FOLHA on line, 2009).

Em 20 de julho de 2005, o Canadá se tornou o primeiro país na América a legalizar as uniões homossexuais, com a promulgação da Lei de Casamento Civil.

Contrariando os protestos da Igreja Católica, em abril de 2005, a Espanha aprovou o projeto que legalizou o casamento entre homossexuais, concedendo os mesmos direitos previstos para as uniões heterossexuais, inclusive com direito à herança, pensão e 
adoção de filhos (REIS, 2005, p. 55). Em maio deste ano, foi sancionada em Portugal a lei que regulamenta as uniões homossexuais, aprovada desde janeiro último no Parlamento (G1, 2010).

Em relação à América Latina, é aprovado o casamento homossexual na Cidade do México, em 21 de dezembro de 2009, com a adoção de crianças, a herança, a união patrimonial para obtenção de crédito bancário e a possibilidade de receber benefícios do seguro social (FOLHA online, 2009). Em 15 de julho de 2010, após 14 horas de discussão, o Senado da Argentina aprovou a lei que autoriza o matrimônio entre pessoas do mesmo sexo $(\mathrm{G} 1,2010)$.

Essa breve explanação acerca da situação das uniões homossexuais no ordenamento jurídico de outras nações permite conjecturar que, não obstante existam posicionamentos desfavoráveis a respeito do tema ou uma maior ou menor flexibilidade para tratar do assunto conforme a cultura em que esteja inserido, os Estados têm se posicionado no sentido de resguardar estas uniões, tutelando-as pela ordem normativa.

Neste aspecto, aproximam-se dos ideais propostos à construção de um Estado Democrático, em que as liberdades conferidas aos seus cidadãos apresentam-se como um dos objetivos mais caros a serem concretizados no âmbito nacional.

\section{AS UNIÕES HOMOSSEXUAIS COMO NOVA FORMA DE ENTIDADE FAMILIAR ReCONHeCida Pela Constituição Federal de 1988}

Não obstante a recorrente menção de alguns doutrinadores ao Princípio da Afetividade, de forma direta ou presumível, ao tratar do tema família no âmbito jurídico, com a devida vênia, salienta-se que neste presente trabalho optou-se por posição diversa.

Adotou-se, portanto, o entendimento de que o afeto, pertencente à esfera existencialista e subjetiva do indivíduo, não deve ser considerado elemento indispensável à constituição das relações familiares, ainda que desejável do ponto de vista moral, nem tão pouco elencado ao patamar de princípio pela ordem jurídica vigente. Neste sentido, é irrefutável a constatação de que a extinção do afeto entre os indivíduos nem sempre acarretará o fim de seu relacionamento.

A retórica que sustenta a importância do afeto para o reconhecimento das relações ditas familiares, desconsidera, sensivelmente, a realidade fática, e nem sempre romântica, sob a qual se estabelece o direito.

Nesse sentido, prelecionam Renata Barbosa de Almeida e Walsir Edson Rodrigues Júnior:

Que o afeto é aspecto inerente às relações familiares, consistindo num dos elementos caracterizadores da família e que, neste sentido, alcança importância considerável, parece indiscutível. O mesmo não se pode dizer, porém, acerca de sua qualidade de princípio jurídico, como defendem alguns. 
Imputar a afetividade tal predicado induz conferir a mesma característica imperativa, exigibilidade. Saliente-se, mais uma vez, que os princípios jurídicos são norma e, por isso, de obrigatória observância. Nisso se assenta a dúvida. A afetividade é passível de cobrança? Pode-se impor a alguém que tenha e preste afeto a outro(s)?

A resposta, crê-se, só pode ser negativa. Se o afeto é um sentimento de afeição para com alguém, soa intrínseco ao mesmo a característica de espontaneidade. É uma sensação que se apresenta, ou não, naturalmente. É uma franca disposição emocional para com outro que não tolera variações de existência: ou há ou não há; e tanto numa como noutra hipótese, o é porque autêntico. Isso impede que, ainda que se pretenda, se possa interferir sob o propósito de exigibilidade nas situações em que ele não se apresentar autonomamente. Insistir nisso é desvirtuar a virtude do afeto. Uma vez imposto não é sincero e, assim, não congrega as qualidades que lhes são próprias, dentre as quais o incentivo a sadia conformação da identidade pessoal dos envolvidos.

Em face de tudo isso, a conclusão emerge por si. A afetividade, embora merecedora de atenção jurídica, o é porque elemento-constitutivo da família e, assim, geradora de certos efeitos na orbita do Direito - como o é nascimento com vida, por exemplo. É elemento fático; porém, não jurídico. (ALMEIDA; RODRIGUES JUNIOR, p. 46)

Todavia, é certo que o texto constitucional de 1988 estabelece uma ordem jurídica que prima pelo respeito às garantias e direitos individuais, cujo objetivo é a construção de uma sociedade livre, justa e solidária.

Ao tratar da família, o texto constitucional, assim dispõe:

Art. 226. A família, base da sociedade, tem especial proteção do Estado. [...] $\S 4^{\circ}$. Entende-se, também, como entidade familiar a comunidade formada por qualquer dos pais e seus descendentes. (BRASIL, 2008, p.68).

Uma leitura desatenta do dispositivo retro-mencionado refutará o argumento de que ele deve ser compreendido como cláusula aberta de interpretação, cujo rol de possibilidades apresentado é citado a título de exemplificação, devendo seu conteúdo ser integrado pelos demais princípios e garantias estabelecidos na Constituição Federal de 1988.

Deve-se atentar, todavia, que a apreciação do capítulo constitucional dedicado à família encontra assento no Princípio da Dignidade Humana, fundamento do Estado Democrático de Direito, e no Princípio da Igualdade e da Liberdade, ambos expressamente consubstanciados no artigo $5^{\circ}$ da Constituição de 1988. 
Com base nesta exposição, entende-se cabível e acertado afirmar que as uniões homossexuais são reconhecidas como entidades familiares pela nova ordem jurídica, visto que o preconceito que há tempos tem sido óbice à concretização deste direito não se coaduna com os princípios norteadores da Carta Constitucional, como bem prenuncia Paulo Luiz Netto Lobo (2002, p. 44-45):

No caput do art. 226 operou-se a mais radical transformação, no tocante ao âmbito de vigência da tutela constitucional à família. Não há qualquer referência a determinado tipo de família, como ocorreu com as constituições brasileira anteriores. Ao suprimir a locação "constituída pelo casamento" (art. 175 da Constituição de 1967-69), sem substituí-la por qualquer outra, pôs sob a tutela constitucional "a família”, ou seja, qualquer família. A cláusula de exclusão desapareceu. O fato de, em seus parágrafos, referir a tipos determinados, para atribuir-lhes certas conseqüências jurídicas, não significa que reinstituiu a cláusula de exclusão, como se ali estivesse a locução "a família, constituída pelo casamento, pela união estável ou pela comunidade formada por qualquer dos pais e seus filhos". A interpretação de uma norma ampla não pode suprimir de seus efeitos situações e tipos comuns, restringindo direitos subjetivos.

No que tange especificamente ao reconhecimento das uniões homossexuais, o autor afirma que, além de invocar as citadas normas da Constituição que protegem as relações familiares, a doutrina também tem se apoiado nos direitos e garantias fundamentais previstos no Artigo $5^{\circ}$, notadamente os que tutelam a liberdade, a igualdade sem distinção de qualquer natureza, a inviolabilidade da intimidade e da vida privada (LOBO, 2002, p. 54).

Urge, portanto, considerar que os novos postulados jurídicos, consubstanciados na Constituição Federal de 1988, apontam para necessidade de se repudiar o preconceito, que é fruto da intolerância e do desconhecimento, que em muito contribui para o cerceamento dos direitos decorrentes da constituição das uniões homossexuais. Estas são, por sua vez, abarcadas pela cláusula que institui as entidades familiares e, portanto, destinatárias das garantias tuteladas pelo ordenamento jurídico pátrio.

\section{A equiparação das Uniões homossexuais À União estável}

Pelo disposto no Artigo 226, § 3º da Constituição da República de 1988, "Para efeito da proteção do Estado, é reconhecida a união estável entre o homem e a mulher como entidade familiar, devendo a lei facilitar sua conversão em casamento”.

Com base neste pressuposto a doutrina divide-se em dois entendimentos. 
O primeiro que inclui a união homossexual dentro do âmbito da união estável, através de uma interpretação extensiva dos direitos fundamentais, pelo recurso da analogia, através do dispositivo constitucional mencionado.

Já o segundo entendimento defende a inconstitucionalidade do referido artigo, pela infringência aos princípios da dignidade da pessoa humana e da igualdade, como objeto de manifestação da atividade originária constituinte.

Seguindo a primeira corrente, Roger Raupp Rios entende que:

A equiparação das uniões homossexuais à união estável, pela via analógica, implica a atribuição de um regime normativo destinado originariamente a situação diversa, ou seja, comunidade formada por um homem e uma mulher.

A semelhança aqui presente, autorizadora da analogia, seria a ausência de vínculos formais e a presença substancial de uma comunidade de vida afetiva e sexual duradora e permanente entre os companheiros do mesmo sexo, assim como ocorre entre os sexos opostos (RIOS, 2000, p.122).

Por outro lado, aqueles que se filiam ao segundo entendimento, defendem que o Supremo Tribunal Federal, nos termos do caput do artigo 102 da Constituição da República de 1988, deve verificar se o artigo 226, § 30 , da Carta Magna, viola os princípios constitucionais e direitos fundamentais, como a dignidade da pessoa humana e a igualdade, presentes no próprio texto constitucional. No que, portanto, deveria julgar a inconstitucionalidade do referido dispositivo constitucional.

Tratar-se-ia de uma inconstitucionalidade da norma constitucional originária.

Tal tese, contudo, é rechaçada pelo próprio Supremo Tribunal Federal, sob o argumento de que no sistema de Constituição rígida, como é o da Constituição da República Federativa do Brasil de 1988, por meio do qual é exigido um processo solene de alteração constitucional, não coaduna com a ideia de normas constitucionais inconstitucionais. Isto é, não há que se falar em hierarquia de normas constitucionais.

De fato, tal entendimento é o que pode ser extraído da emenda da decisão da ADI n. 815 de relatoria do Ministro Moreira Alves:

EMENTA: - Ação direta de inconstitucionalidade. Parágrafos $1^{\circ}$ e $2^{\circ}$ do artigo 45 da Constituição Federal. - A tese de que há hierarquia entre normas constitucionais originárias dando azo à declaração de inconstitucionalidade de umas em face de outras e incompossível com o sistema de Constituição rígida. - Na atual Carta Magna "compete ao Supremo Tribunal Federal, precipuamente, a guarda da Constituição" (artigo 102, “caput”), o que implica dizer que essa jurisdição lhe é atribuída para impedir que se desrespeite a Constituição como um todo, e não para, com relação a ela, exercer o papel de fiscal do Poder Constituinte originário, a fim de verificar se este teria, ou não, violado os princípios de direito suprapositivo que ele próprio 
havia incluído no texto da mesma Constituição. - Por outro lado, as cláusulas pétreas não podem ser invocadas para sustentação da tese da inconstitucionalidade de normas constitucionais inferiores em face de normas constitucionais superiores, porquanto a Constituição as prevê apenas como limites ao Poder Constituinte derivado ao rever ou ao emendar a Constituição elaborada pelo Poder Constituinte originário, e não como abarcando normas cuja observância se impôs ao próprio Poder Constituinte originário com relação as outras que não sejam consideradas como cláusulas pétreas, e, portanto, possam ser emendadas. Ação não conhecida por impossibilidade jurídica do pedido (BRASIL, 1996).

Ademais, entende-se que não é aplicável a inconstitucionalidade do artigo 226, $\S 3^{\circ}$ da Constituição, pois a interpretação da norma constitucional não deve se dar através da extração de significados de expressões isoladas, mas de acordo com a harmonização de princípios e regras em que ela está vinculada.

Como linha de pensamento, adota-se parcialmente a primeira corrente, lançando mão da analogia entre uniões estáveis e uniões homossexuais apenas quanto aos efeitos legais. No que tange ao reconhecimento como entidade familiar, a união homossexual encontra amparo diretamente na cláusula aberta de entidades familiares do texto constitucional (artigo 226, $\S 4^{\circ}$ ), uma vez que tal interpretação é a mais adequada no contexto de Estado Democrático de Direito.

Corroborando o fato de a Constituição de 1988 trazer uma cláusula aberta de entendidas familiares junto ao seu Artigo 226, Paulo Luiz Netto Lôbo (2002, pp.43/46) conclui que:

[...] Além do princípio da igualdade das entidades, como decorrência natural do pluralismo reconhecido pela Constituição, há de se ter presente o princípio da liberdade de escolha, como concretização do macro princípio da dignidade da pessoa humana. Consulta a dignidade da pessoa humana a liberdade de escolher e constituir a entidade familiar que melhor corresponda à sua realização existencial. Não pode o legislador definir qual a melhor e mais adequada.

[...] Não é a família per se que é constitucionalmente protegida, mas o locus indispensável de realização e desenvolvimento da pessoa humana. Sob o ponto de vista do melhor interesse da pessoa, não podem ser protegidas algumas entidades familiares e desprotegidas outras, pois a exclusão refletiria nas pessoas que as integram por opção ou por circunstâncias da vida, comprometendo a realização do princípio da dignidade humana.

Defende-se a assertiva acima respaldada pelo princípio da máxima efetividade da interpretação constitucional, nos termos dos ensinamentos de J. J. Gomes Canotilho: 
[...] a uma norma constitucional deve ser atribuído o sentido que maior eficácia lhe dê. É um princípio operativo em relação a todas e quaisquer normas constitucionais, e embora a sua origem esteja ligada à tese da actualidade das normas programáticas (Thoma), é hoje sobretudo invocado no âmbito dos direitos fundamentais (no caso de dúvidas deve preferir-se a interpretação que reconheça maior eficácia aos direitos fundamentais) (CANOTILHO, 1993, p.227).

Portanto, se forem atribuídos dois sentidos possíveis ao artigo 226 da Constituição, deve ser aplicado aquele que alcança a inclusão de todas as entidades familiares, devido dar maior eficácia ou eficiência aos princípios de "especial proteção do Estado", no caput deste artigo, e da dignidade da pessoa humana "de cada um que a integram”, disposto no $\S 8^{\circ}$ do referido dispositivo. Deve-se também ter em vista que tal interpretação é a que melhor atende às garantias e os direitos fundamentais contidos no texto constitucional.

Não se olvida, porém, que é viável um regramento específico para as uniões homossexuais. Afinal, os direitos e deveres a serem conferidos a elas não devem ser os mesmos das uniões estáveis entre pessoas de sexos opostos, e, uma vez que a lei não discrimina, é defeso ao legislador e ao intérprete o fazerem, salvo se a discriminação estivesse expressamente prevista na Constituição, o que não é o caso.

Afinal, admitir que a aplicação analógica dos artigos 1.723 a 1.727 do Código Civil de 2002 e dos dispositivos constitucionais que tratam da união estável possam ficar ao arbítrio do poder discricionário dos juízes e tribunais, no que tange ao reconhecimento dos direitos dos indivíduos que compõem a união homossexual, é violar direitos fundamentais destes indivíduos.

Justifica-se tal entendimento em referência aos princípios da igualdade e da dignidade da pessoa humana, previstos, respectivamente, nos artigos $5^{\circ}$, caput e $1^{\circ}$, inciso III da Constituição da República de 1988. Afinal, a união homossexual, como nova configuração de entidade familiar, enseja que todos os seus aspectos sejam regulamentados por meio de lei infraconstitucional, fixando todos os direitos e deveres que integram os indivíduos que a compõem, tais como o regime de comunhão, os direitos sucessórios, a adoção dentre outros.

De acordo com Roger Raupp Rios:

[...] a união estável distingue-se das uniões homossexuais precisamente em virtude do requisito da diversidade sexual entre os companheiros, expressamente consignado no texto do art. $226, \S 3^{\circ}$, bem como na determinação constitucional de se facilitar sua conversão em casamento, aspecto que também afasta as uniões homossexuais da união estável (RIOS, 2002, p.513). 
Conclui-se que, devido à peculiaridade em que tal entidade familiar é a união homossexual, entende-se que é mais adequado às suas tratativas em um dispositivo legal próprio, justificado pelo Estado Democrático de Direito, e os princípios basilares de nossa Constituição, onde o seu reconhecimento se dá pela cláusula aberta do artigo 226 do texto constitucional.

\section{O Projeto de Lei i. I5I/95: UNiÃo CiVIL ENTRE PeSSOAS do MESMO SEXo}

O Projeto de Lei n. 1.151, de autoria da ex-deputada Marta Suplicy - PT/SP, permanece sujeito à apreciação pelo Plenário da Câmara dos Deputados desde o dia 14 de agosto de 2007.

O referido projeto visa disciplinar a união civil entre pessoas do mesmo sexo, regulamentando, por exemplo, "a transmissão de bens patrimoniais quando da abertura da sucessão, benefícios previdenciários, seguro-saúde, declaração conjunta do imposto de renda, direito à curatela e à nacionalidade brasileira, no caso de estrangeiros" (REIS, 2005, p. 54).

Ao justificar a propositura do Projeto de Lei n. 1.151/95, a deputada assim ponderou acerca de seus aspectos jurídicos:

O projeto de lei que disciplina a união civil entre pessoas de mesmo sexo vem regulamentar, através do direito, uma situação que há muito, já existe de fato. E, o que de fato existe, de direito não pode ser negado.

A criação desse novo instituto legal é plenamente compatível com o nosso ordenamento jurídico, tanto no que se refere a seus aspectos formais quanto de conteúdo. È instituto que guarda perfeita harmonia com os objetivos fundamentais da República Federativa do Brasil - constitucionalmente garantidos - de construir uma sociedade livre, justa e solidária e promover o bem de todos, sem preconceitos de origem, raça, cor, idade e quaisquer outras formas de discriminação (art. $3^{\circ}$, I e IV CF) (BRASIL, 1995).

Com relação à natureza do Projeto de Lei em comento, alvo de polêmicas e equívocos no meio social, a autora esclarece:

A figura da união civil entre pessoas do mesmo sexo não se confunde nem com o instituto do casamento, regulamentado pelo Código Civil Brasileiro, nem com a união estável, prevista no parágrafo $3^{\circ}$, do art.226 da Constituição Federal. É mais uma relação entre particulares que, por sua relevância e especificidade, merece a proteção do Estado e do Direito (BRASIL, 1995).

Percebe-se, neste diapasão, ser a posição apresentada acima a mesma adotada neste 
trabalho, ou seja, de que a união homossexual apresenta particularidades que as distingue das demais explicitadas no ordenamento jurídico, não podendo, portanto, ser tratada como união estável ou outro tipo.

Em seus artigos $1^{\circ}$ e $2^{\circ}$, o Projeto de Lei n. $1.151 / 95$ estabelece que:

Art. $1^{\circ}$ - É assegurado a duas pessoas do mesmo sexo o reconhecimento de sua união civil, visando a proteção dos direitos à propriedade.

Art. $2^{\circ}$ - A união civil entre pessoas do mesmo sexo constitui-se mediante registro em livro próprio, nos Cartórios de Registros Civil de Pessoas Naturais (BRASIL, 1995).

Caso seja aprovado o projeto de lei mencionado, deverá ser o registro da união feito em livro próprio, afastada a hipótese de mudança no estado civil dos envolvidos na relação. Caso seja realizado com mais de uma pessoa, o contrato será nulo, podendo o infrator responder penalmente por falsidade ideológica. Portanto, somente poderá ser celebrado novo contrato se o anterior for desfeito, conforme dispõe o artigo $4^{\circ}$ do Projeto de Lei n. 1.151/95 (REIS, 2005, p. 54).

Sobre o tema, preleciona Álvaro Villaça Azevedo sobre o Projeto de Lei:

$\mathrm{O}$ art. $9^{\circ}$ institui o bem de família, como disciplinado pela lei $\mathrm{n}^{\circ} 8.009$, de 1990. Já os artigos 10 e 11 estabelecem, respectivamente, o direito à inscrição do parceiro como beneficiário do Regime Geral de Previdência Social, na qualidade de dependente, e como beneficiário de pensão, nos moldes da Lei $n^{\circ} 8.112 / 90$.

Em seus artigos 16 e 17, a proposta mostra-se de grande utilidade social, porquanto prevê a composição de rendas para a aquisição de casa própria; reconhece o direito dos parceiros a plano de saúde e seguro de vida em grupo e autoriza a inscrição de um e de outro como dependente, com efeitos na legislação tributária (deduções, principalmente) (AZEVEDO, 2004, p. 44).

Entretanto, é mister salientar que o referido Projeto de Lei falha ao não contemplar no âmbito das uniões homossexuais a possibilidade de obter a guarda ou tutela, em conjunto, de crianças ou adolescentes, ainda que sejam filhos biológicos de um dos contraentes, não obstante a jurisprudência tenha avançado neste sentido.

Com o objetivo de requerer a inclusão na ordem do dia, junto ao processo legislativo do Projeto de Lei n. 1.151/95, que foi retirado da pauta em razão de acordo entre lideranças desde 31 de maio de 2005, o Deputado Celso Russomanno ofereceu o requerimento n. 1447/2007, em que aduz: 
[...] Um País que estabeleceu em sua Constituição Federal o respeito à diversidade cultural e de pensamento, a proteção à intimidade e à vida privada e à liberdade de expressão não pode omitir-se na luta de milhões de brasileiros que seguem uma orientação sexual diferente da maioria.

O respeito à dignidade da pessoa humana impede ao Estado a imposição de uma moral determinada. Ao invés, é dever dos governantes garantir um âmbito de autonomia e liberdade para que cada um possa desenvolver a própria personalidade. [...] (BRASIL, 2007)

Não obstante o Projeto de Lei n. 1.151/95 represente um passo significativo do Legislador na concretização dos direitos decorrentes da constituição das uniões homossexuais, é prudente considerar que o mesmo necessita ser discutido com seriedade e compromisso pelos parlamentares cuja participação deve gerar emendas no sentido de melhor alinhá-lo com as garantias previstas na Carta Constitucional.

\section{As UNIÕes HomosseXuAis E A ADPF I32 e ADI 4.277}

Como mais uma forma de fundamentar e legitimar a união homossexual, destacamos a ADPF 132 e ADI 4.277. Elas pretendem o reconhecimento das uniões homossexuais pela ordem jurídica, no sentido de que não é necessária uma lei para que a união seja reconhecida, conforme defendido no presente trabalho.

A ADPF é um instrumento de controle de constitucionalidade previsto no artigo $102, \S 1^{\circ}$ da Constituição da República de 1988 e disposta nos artigos $1^{\circ}$ e seguintes da Lei n. 9.882/1999, com o fim de arguir descumprimento de preceito fundamental.

A ADPF 132, ajuizada pelo governador do Estado do Rio de Janeiro, Sérgio Cabral, em 27 de fevereiro de 2008, indica como violação os preceitos fundamentais do direito da igualdade, conforme artigo $5^{\circ}$ caput, o direito de liberdade, pela autonomia da vontade, conforme artigo $5^{\circ}$, inciso II; e o princípio da segurança jurídica, conforme artigo $5^{\circ}$ caput, todos previstos na Constituição da República de 1988.

Ela indica como atos do poder público causadores da lesão o Estatuto dos Servidores Civis do Estado do Rio de Janeiro, interpretado de maneira discriminatória contra os homossexuais; e o conjunto de decisões proferidas pelos tribunais estaduais, em ênfase o do Rio de Janeiro, que negam às uniões homoafetivas o mesmo regime jurídico que as uniões estáveis. A ADPF 132 utiliza a expressão união homoafetiva, o que entendemos não ser a expressão mais adequada, pois a afetividade não é um princípio jurídico, conforme já trabalhado neste estudo.

As teses postas na ADPF ilustram a evolução da sociedade, evidenciando as relações homossexuais como fatos do cotidiano. Afinal, tais uniões sempre existiram e vão existir independente do seu reconhecimento jurídico. Entretanto, torna-se 
necessária sua proteção, a fim de evitar insegurança nas decisões judiciais e garantir o livre desenvolvimento da personalidade de seus membros.

Como fundamento jurídico a ADPF trata da equiparação da união homoafetiva à união estável regulamentada no artigo 1.723 do Código Civil de 2002, pretendendo, em recurso à analogia, evitar discriminação inconstitucional, devido à afetividade, que merece tutela do direito. A ADPF faz menção de jurisprudências e que a maioria delas não reconhece a união homoafetiva à união estável.

A ADPF 132 também tem como fundamento à proteção jurídica aos servidores públicos do Estado Rio de Janeiro que mantém união homoafetiva, e que, portanto sentem-se no direito de terem os seus direitos reconhecidos, no sentido das mesmas garantias dos servidores que possuem relacionamentos heterossexuais.

Ela apresenta como solução os seus fundamentos jurídicos, sob pena de produzir violação a preceitos fundamentais. Portanto, pelo emprego da analogia, deve-se estender o regime jurídico da união estável, previsto no art. 1723 do Código Civil, às uniões entre pessoas do mesmo sexo, pois esta apresenta os mesmos elementos para a configuração daquela, justificada pela interpretação da legislação ordinária à luz dos princípios constitucionais.

Junto aos seus pedidos, a ADPF 132 contempla medida liminar a fim de evitar mais decisões que possam gerar a frustração dos direitos fundamentais dos homossexuais, bem como a validação de decisões administrativas no sentido de equiparar as uniões homossexuais à união estável. Por pedido principal, reconhecer a união homoafetiva à união estável, em recurso à analogia pelo artigo 1723 do Código Civil de 2002. E, por fim, por pedido subsidiário, em caso de descabimento da ADPF a sua conversão em Ação Direta de Inconstitucionalidade, pois o que se pretende é a interpretação conforme a Constituição.

A ADPF 132 está em tramitação no Supremo Tribunal Federal, cujo andamento processual está conclusos ao relator em 02 de outubro de 2009 (BRASIL, 2008).

Maria Berenice Dias, em encontro com o Presidente do STF, Ministro Gilmar Mendes, em 26 de março de 2009, de acordo com o site do direito, afirmou que:

[...] o preconceito é uma das razões que impedem o avanço desse tema no âmbito do Legislativo. As pessoas que se envolvem nesse tema, que defendem de alguma maneira, acabam sendo rotulados de homossexuais; como se as pessoas não pudessem defender causas que não lhe dissessem pessoalmente. (AT/AM, 2009).

A ADPF 132 é um avanço na busca da conquista dos direitos dos homossexuais, que mesmo se julgada desfavorável, abrirá, se já não abriu, precedentes para várias outras conquistas dos direitos humanos, a fim de equalizar a diversidade sexual objetivando o Estado Democrático de Direito, conforme preceitua nossa Constituição. 
Por outro lado, A Arguição de Descumprimento de Preceito Fundamental n. 178, proposta pela Procuradoria Geral da República, que versa acerca do reconhecimento da união entre pessoas do mesmo sexo como entidade familiar, foi reautuada como Ação Direta de Inconstitucionalidade n. 4.277, segundo determinação do Presidente do Supremo Tribunal Federal, Ministro Gilmar Mendes, em 21 de julho de 2009.

Em seu preâmbulo, a Procuradoria Geral esclarece o objetivo deste instrumento é obter da Suprema Corte a declaração:

[...] (a) que é obrigatório o reconhecimento, no Brasil, da união entre pessoas do mesmo sexo como entidade familiar, desde que atendidos os requisitos exigidos para a constituição de união estável entre homem e mulher; e (b) que os mesmos direitos e deveres dos companheiros nas uniões estáveis estendem-se aos companheiros nas uniões entre pessoas do mesmo sexo. [...] (BRASIL, 2009)

Ao expor os fatos que ensejam a propositura da presente ação, a Procuradoria Geral da República argumenta que as uniões homossexuais são uma realidade fática inegável em todo mundo, existido desde os primórdios da humanidade. Entretanto, com a liberalização dos costumes e com o fortalecimento dos movimentos que lutam pelos direitos atinentes aos homossexuais, a visibilidade do tema e a discussão acerca do assunto acentuou-se, com sensível diminuição do preconceito que historicamente o envolvia (BRASIL, 2009).

Ressalve-se, ainda, a importante reflexão exarada neste instrumento, ao propugnar que certas visões preconceituosas e anacrônicas sobre a homossexualidade devem ser superadas, como, por exemplo, aquela que, sustentada pela Igreja, a compreendia como 'pecado', posicionamento este incompatível com os princípios da liberdade de religião e da laicidade (Constituição da República artigos $5^{\circ}$, inciso VI e 19, inciso I) ou, ainda, a que a tratava como doença, ideia hoje rechaçada pela Medicina e pela Psicologia (BRASIL, 2009).

Ao apresentar os fundamentos que ensejam a Ação Direta de Inconstitucionalidade n. 4.277, a Procuradoria Geral da República compreende que a inserção das uniões homossexuais na cláusula aberta das entidades familiares tem como escopo uma interpretação harmoniosa e integrativa dos princípios esculpidos na Constituição da República de 1988. Em seguida, aponta uma alternativa hermenêutica para sanar a omissão legislativa acerca do tema:

A tese sustentada nesta ação é a de que se deve extrair diretamente da Constituição de 88, notadamente dos princípios da dignidade da pessoa humana (art. $1^{\circ}$, inciso III), da igualdade (art. $5^{\circ}$, caput), da vedação de discriminações odiosas (art. $3^{\circ}$, inciso IV), da liberdade (art. $5^{\circ}$, caput) e da proteção à segurança jurídica, a obrigatoriedade do reconhecimento da união entre 
pessoas do mesmo sexo como entidade familiar. E diante da inexistência de legislação infraconstitucional regulamentadora, devem ser aplicadas analogicamente ao caso as normas que tratam da união estável entre homem e mulher (BRASIL, 2009).

Reitera, portanto, a necessidade de tratamento legal específico das uniões homossexuais para efetivação dos direitos-garantias previstos na Carta Constitucional, visto que esta ausência de regulamentação legal vem comprometendo, na prática, o exercício de direitos fundamentais pelos homossexuais, em contraposição à situação vivida pelos casais heterossexuais.

Outrossim, é mister observar que Ação Direta de Inconstitucionalidade 4.277, proposta pela Procuradoria Geral da República coaduna com os princípios basilares do Estado Democrático de Direito inserido pela Constituição Federal de 1988, e que tem como fundamento o princípio da dignidade da pessoa humana e como finalidade a construção de uma sociedade livre, justa e solidária. Ao provocar o posicionamento da Suprema Corte sobre as uniões homossexuais, a Ação Direta de Inconstitucionalidade n. 4.277, ainda pendente de julgamento, sinaliza o advento de importante precedente no cenário jurídico, cujo alcance será de relevante importância na interpretação e concretização dos direitos em debate.

\section{CONCLUSÃO}

A Constituição da República de 1988 anuncia o fim de um período de ostracismo e atrofia do exercício da cidadania e o início de uma nova ordem jurídica, que ao instituir o Estado Democrático de Direito, tem como fundamento a efetivação do princípio da dignidade da pessoa humana e preceitua a defesa dos direitos e garantias individuais esculpidos no texto constitucional.

Neste contexto, surge a constatação de que o ordenamento jurídico necessita ser reinterpretado a partir de uma hermenêutica constitucional, de forma a se assegurar a harmonia do sistema mediante as diretrizes principiológicas inseridas pela Constituição de 1988.

Outrossim, fala-se em crise do direito, uma vez reconhecidos os novos paradigmas constitucionais que conformam a atuação do operador do direito na interpretação das normas que compõem o ordenamento jurídico.

No direito das famílias, tal crise se instala a partir do reconhecimento de arranjos familiares que se afastam do modelo tradicional, mas que são abarcados pela cláusula aberta das entidades familiares instituída no artigo 226, § 4 , da Constituição de 1988.

Neste sentido, conclui-se, portanto, que as uniões homossexuais devem ser consideradas entidades familiares, por força do dispositivo supracitado, e que deve o legislador, dirigido pelos princípios presentes na Carta Constitucional, assegurar a efi- 
cácia dos direitos e garantias decorrentes da constituição destas uniões, não se deixando levar por juízos morais e religiosos incompatíveis com a nova ordem jurídica vigente.

Portanto, entende-se que está vedado ao Estado a imposição de uma pretensa moral comum a todos em uma democracia. Destarte, garantem-se iguais liberdades fundamentais e a co-vivencia de vários projetos de vida.

: ARTIGO APROVADO (21/08/2010) : RECEBIDO EM 30/07/2010

NOTAS

1 Segundo explica Gregório Assagra de Almeida (2008, pp. 18-19), "O pós-positivismo pretende superar a legalidade estrita, mas não despreza o direito posto. [...] Nesse conjunto de concepções ricas e heterogêneas, ainda em construção, estão a atribuição de normativa aos princípios e a fixação de suas relações com os valores e as regras".

\section{REFERÊNCIAS BIBLIOGRÁFICAS}

ALMEIDA, Renata Barbosa de; RODRIGUES JÚNIOR, Walsir Edson. Curso de direito das famílias. No prelo. ALMEIDA, Gregório Assagra. O Ministério Público no Neoconstitucionalismo: Perfil Constitucional e Alguns Fatores de Ampliação de sua Legitimação Social. In: CHAVES, Cristiano; ALVES, Leonardo Barreto Moreira; ROSENVALD, Nelson. Temas atuais do Ministério Público. Rio de Janeiro: Lumen Juris, 2008, pp. 17-59.

AT/AM. Direitos dos homossexuais é tema de reunião com presidente do STF. Direito2, 26 de março de 2009. Disponível em: http://www.direito2.com.br/stf/2009/mar/26/direitos-dos-homossexuais-e-tema-de-reuniao-compresidente-do-stf. Acesso em: 09 out. 2009.

AZEVEDO, Álvaro Villaça. União homoafetiva. Consulex: Revista Jurídica, Brasília, v.8, n.181, p.42-44, jul.2004. BENCKE, Carlos Alberto. Partilha dos bens na união estável, na união homossexual e no concubinato impuro. Revista Brasileira de Direito de Família, v. 4, n. 14, pp. 20-42, jul-set 2002.

BRASIL. Projeto de Lei 1.151 de 1995. Disciplina a união civil entre pessoas do mesmo sexo e dá outras providências. Disponível em: <http://www2.camara.gov.br/proposicoes/loadFrame.html?link=http://www.camara.gov.br/ internet $/$ sileg $/$ prop_lista.asp?fMode $=1 \&$ btnPesquisar $=$ OK\&Ano $=1995 \&$ Numero $=1151 \&$ sigla $=$ PL $>$. Acesso em: 28 ago. 2009.

BRASIL. Superior Tribunal de Justiça. Recurso Especial n. $820475 / R J .4^{a}$ Turma julgadora. Relator Ministro Antônio de Pádua Ribeiro. Data do julgamento em 02/09/2008. Data da publicação em 06/10/2008. Disponível em: http://www.stj.jus.br/SCON/jurisprudencia/toc.jsp?tipo_visualizacao=RESUMO\&livre=Recurso+Especial $+820475 \& \mathrm{~b}=$ ACOR. Acesso em: 10 out. 2009.

BRASIL. Supremo Tribunal Federal. ADI 815. Disponível em: <http://www.stf.jus.br/portal/jurisprudencia/ listarJurisprudencia.asp?s1=(ADI\$.SCLA. E 815.NUME.) OU (ADI.ACMS. ADJ2815.ACMS.)\&base=baseAcordaos> . Acesso em: 14 nov. 2009.

BRASIL. Supremo Tribunal Federal. ADI 4.277. Disponível em: <http://www.stf.jus.br/portal/peticaoInicial/ verPeticaoInicial.asp?base $=$ ADIN\&s1 $=4277 \&$ processo $=4277>$. Acesso em: 28 ago. 2009.

BRASIL. Supremo Tribunal Federal. ADPF 132. Disponível em: <http://www.stf.jus.br/portal/peticaoInicial/ verPeticaoInicial. asp?base $=$ ADPF\&s1 $=132 \&$ processo $=132>$. Acesso em: 28 ago. 2009. 
BRASIL. Tribunal Superior Eleitoral. Recurso Especial n. 24564. Relator. Min. Gilmar Mendes. Julgado em 01/10/2004. Data da publicação em 01/10/2004. Disponível em: <http://www.tse.jus.br/sadJudSjur/pesquisa/ actionBRSSearch.do?toc $=$ true $\&$ docIndex $=0 \&$ httpSessionName $=$ brsstateSJUT2 $8400416 \&$ sectionServer $=$ TSE $>$. Acesso em: 10 out. 2009.

CANOTILHO, José Joaquim Gomes. Direito constitucional, 6. ed. Coimbra: Livraria Almedina, 1993. 1228p. COSTA FREIRE, Jurandir. A questão psicanalítica da identidade sexual. In: Graña, Roberto (org.). Homossexualidade. Formulações psicanalíticas atuais. Porto Alegre: Artes Médicas, 1998, pp. 15-27.

DAGNESE, Napoleao. Cidadania no armário: uma abordagem sócio-jurídica acerca da homossexualidade. São Paulo: LTR, 2000.

DIAS, Maria Berenice. Família Homoafetiva. In: TEIXEIRA, Ana Carolina Brochado; RIBEIRO, Gustavo Pereira Leite. Manual de direito das famílias e das sucessões. Belo Horizonte: Del Rey e Mandamentos, 2008, pp. 169-191. Manual de direito das famílias, 5. ed. Porto Alegre: Livraria do Advogado, 2009. 608p. (da homossexualidade). São Paulo: LTR, 2000. União homoafetiva: o preconceito e a justiça, 4. ed. São Paulo: Revista dos Tribunais, 2010.

. Uniões homoafetivas: uma realidade que o Brasil insiste em não ver. Revista Justiça \& História, v. 2, n. 3, 2002, pp. 399-414.

FACHIN, Luiz Edson. Aspectos jurídicos da união de pessoas do mesmo sexo. Revista da Faculdade Mineira de Direito, v. 3, n. 5 e 6, 2000, pp.147-153.

FACHIN, Luiz Edson. Elementos críticos do direito de família: curso de direito civil. Rio de Janeiro: Renovar, 1999. 346p. FIUZA, César. Direito civil: curso completo, 9. ed. Belo Horizonte: Del Rey, 2006. 1083p.

FIUZA, César; SÁ, Maria de Fátima Freire de; NAVES, Bruno Torquato de Oliveira. Direito civil: atualidades. Belo Horizonte: Del Rey, 2003. 331p.

FOUCAULT, Michel. História da sexualidade I: a vontade de saber. Rio de Janeiro: Graal, 1993.

FOLHA on line. Em decisão inédita na América Latina, Cidade do México aprova união gay. $21 \mathrm{dez} 2009$. Disponível em: <http://www1.folha.uol.com.br/folha/mundo/ult94u669841.shtml>. Acesso em: 12 jan. 2010.

FOLHA on line. Corte Suprema da Califórnia proíbe casamento gay no Estado. 26 maio 2009. Disponível em: < http://www1.folha.uol.com.br/folha/mundo/ult94u571864.shtml>. Acesso em: 14 nov. 2009.

G1, mundo. Após 14 horas de debate, Senado da Argentina aprova casamento gay. 15 jul. 2010. Disponível em:

<http://g1.globo.com/mundo/noticia/2010/07/senado-da-argentina-aprova-o-casamento-gay.html>. Acesso em: 20 out. 2010.

G1, mundo. Portugal faz seu $1^{\circ}$ casamento gay. 07 jun. 2010. Disponível em: <http://g1.globo.com/mundo/noticia/ 2010/06/portugal-faz-seu-1-casamento-gay.html>. Acesso em: 20 out. 2010.

GOMES, Andréa Barroso. Regulamentação da união entre o par homoafetivo. 2003. 51f. Monografia (Conclusão de Especialização) - Pontifícia Universidade Católica de Minas Gerais, Instituto de Educação Continuada HABERMAS, Jürgen. Direito e democracia: entre facticidade e validade, 2. ed., v.1. Rio de Janeiro: Tempo Brasileiro, 2003. pp. 128-131.

LIMA, Giselli de Almeida Tamarozzi. A família homossexual: demandas e desafios para o serviço social. Construindo o Serviço Social, v. 16, jul-dez 2005, pp. 31-58.

LÔBO, Paulo Luiz Netto. Entidades familiares constitucionalizadas: para além do numerus clausus. Revista Brasileira de Direito de Família, v. 3, n. 12, jan-mar 2002, pp. 40-55.

MARTINEZ, Wladimir Novaes. Direitos previdenciários na união homoafetiva. Revista IOB de Direito de Família, v. 9, n. 52, fev-mar 2009, p.07-11.

MINAS GERAIS. Tribunal de Justiça de Minas Gerais. Apelação cível n. 10024069303246/001(1). Relator. Des. Heloísa Combat. Data da publicação em 27/07/2007. <http://www.tjmg.jus.br/juridico/jt_/ juris_resultado.jsp?tipoTribunal $=1 \&$ comrCodigo $=0024 \&$ ano $=06 \&$ txt_processo $=930324 \& \mathrm{dv}=6 \&$ complemento $=$ 001\&acordaoEmenta $=$ acordao\&palavrasConsulta $=\&$ tipoFiltro $=$ and\&orderByData $=0$ \&relator $=\&$ dataInicial $=$ \&dataFinal $=16 \% 2 \mathrm{~F} 10 \% 2 \mathrm{~F} 2009 \&$ resultPagina $=10 \&$ dataAcordaoInicial $=\&$ dataAcordaoFinal $=$ \&pesquisar $=$ Pesquisar $>$. Acesso em: 10 out. 2009.

MIRANDA, Fábio Guimarães. União civil homoafetiva no direito brasileiro, 2006. 69f.

Monografia (Conclusão de Curso) - Pontifícia Universidade Católica de Minas Gerais, Faculdade Mineira de Direito. MOTT, Luiz R. B. Homossexualidade: mitos e verdades. Salvador: Grupo Gay da Bahia, 2003. 132p.

OLIVEIRA, Basílio de. Concubinato. Rio de Janeiro: Novos Rumos, 1997. 397p. PINTO, Antonio Luiz de Toledo; WINDT, Márcia Cristina Vaz dos Santos; CÉSPEDES, Livia (Org.). Vade mecum Saraiva 2008. Obra coletiva de autoria da Editora Saraiva com a colaboração de Antonio Luiz de Toledo Pinto, Márcia Cristina Vaz dos Santos Windt e Livia Céspedes, 5. ed. São Paulo: Saraiva, 2008. 1738 p. POLI, Leonardo Macedo. Aspectos civis da homossexualidade, 2004. 39f. Projeto de pesquisa - Pontifícia Universidade Católica de Minas Gerais, Faculdade Mineira de Direito. 
REIS, Roberta Ferreira. Legítimo direito de cidadania: uma tentativa de justificar a homossexualidade. Revista Jurídica Consulex, v. 9, n. 205, jul. 2005, p. 52-55.

RIO GRANDE DO SUL. Tribunal de Justiça do Estado. Agravo de Instrumento n. 599075496. Rel. Des. Breno Moreira Mussi. Julgado em 17/06/1999. Data da publicação: Diário da Justiça do dia <http://www.tjrs.jus.br/site_php/ jprud2/ementa.php>. Acesso em: 10 out. 2009.

RIO GRANDE DO SUL. Tribunal de Justiça do Estado. Apelação cível n. 70002355204. Rel. Des. Sérgio Fernando de Vasconcellos Chaves. Julgado em 11/04/2001. Data da publicação: Diário da Justiça do dia < http://www.tjrs.jus.br/site_php/jprud2/ementa.php>. Acesso em: 10 out. 2009.

RIOS, Roger Raupp. Dignidade da pessoa humana, homossexualidade e família: reflexões sobre as uniões de pessoas do mesmo sexo. In: COSTA, Judith Martins. A reconstrução do direito privado: reflexos dos princípios, diretrizes e direitos fundamentais constitucionais no direito privado. São Paulo: Revista dos Tribunais, 2002. pp. 483-517. SILVA, Tatiana Nascimento da. Um novo paradigma para atribuição de efeitos jurídicos às uniões entre homossexuais. Justiça do Direito, v.16, n. 2, jan. 2002, pp. 433-439.

TOURAINE, Alain. O direito ao casamento gay. Folha de São Paulo, São Paulo, 21 mar. 2004. Mais, n. 631, p. 3.

Avenida do Contorno, 7069 Santo Antônio - 30110-043 Belo Horizonte - MG - Brasil fernandohortalahotmail.com

\section{Avenida Afonso Pena, 4114, 401 Cruzeiro - 30130-009 Belo Horizonte - MG - Brasil iasbhzagmail.com}

Rua Santo Antônio, 29 São Paulo - 31910-290 Belo Horizonte - MG - Brasil isaac.espindolalayahoo.com.br

Rua Castelo de Edimburgo, 184 Castelo - 31330-240 Belo Horizonte - MG - Brasil 15abol.com.br

\section{Fernando Horta Tavares}

PÓS-DOUTOR EM DIREITO CONSTITUCIONAL PELA Universidade Nova de Lisboa DOUTOR E MESTRE EM DIREITO E EM DIREITO PROCESSUAL Pela Pontifícia Universidade Católica DE Minas Gerais (PUC/MG)

PROFESSOR DA GRADUAC̣ÃO E DA PÓS-GRADUAC̣ÃO da Faculdade Mineira de Direito da PontifícIa Universidade Católica Minas Gerais (PUC/MG)

Advogado

\section{Iara Antunes de Souza}

Mestranda em Direito Privado pela Pontifícia Universidade Católica de Minas Gerais (PUC/MG)

ESPECIALISTA EM DiREITO CIVIL PELA UGF/CAD Especialista EM Direito Processual PELA Unama/LFG Membro do Centro de Estudos em Biodireito (Cebid) Professora da Faculdade Pitágoras - Unidade Betim

Advogada

\section{Isaac Espíndola Vitorino Ferreira}

Graduando da Faculdade Mineira de Direito da Pontifícia Universidade Católica de Minas Gerais (PUC/MG)

\section{Tiago Vieira Bomtempo}

Graduando da Faculdade Mineira de Direito da Pontifícia Universidade Católica de Minas Gerais (PUC/MG) 